\title{
Total Replacement of Millet Silage with BRS-716 Biomass Sorghum Silage in Crossbred Dairy Heifers Diets: Nutrient Intake and Digestibility, Microbial Protein Synthesis, Ingestive Behavior, and Growth Performance
}

\section{Fernanda Ferreira da Hora}

UNIMONTES: Universidade Estadual de Montes Claros

Vicente Ribeiro Rocha Júnior

UNIMONTES: Universidade Estadual de Montes Claros

Flávio Pinto Monção ( $\square$ moncaomoncao@yahoo.com.br)

Universidade Estadual de Montes Claros https://orcid.org/0000-0002-9821-0107

João Paulo Sampaio Rigueira

UNIMONTES: Universidade Estadual de Montes Claros

Matheus Wilson Silva Cordeiro

UNIMONTES: Universidade Estadual de Montes Claros

Fernanda Naiara Fogaça da Cruz

UNIMONTES: Universidade Estadual de Montes Claros

Ícaro Daniel Alves dos Santos Souza

UNIMONTES: Universidade Estadual de Montes Claros

Amanda Maria Silva Alencar

UNIMONTES: Universidade Estadual de Montes Claros

Carlos Juliano Brant Albuquerque

UNIMONTES: Universidade Estadual de Montes Claros

Dijair Barbosa Leal

UNIMONTES: Universidade Estadual de Montes Claros

Research Article

Keywords: Forage alternatives, animal intake, heifers, semi-arid rangeland

Posted Date: July 7th, 2021

DOI: https://doi.org/10.21203/rs.3.rs-659701/v1 
License: (c) (i) This work is licensed under a Creative Commons Attribution 4.0 International License. Read Full License 


\section{Abstract}

This study addressed the different proportions of millet and sorghum silage biomass BRS 716 (BRS-716 silage) in the diet of crossbred heifers $1 / 2$ to $3 / 4$ Holstein $x$ Zebu on their nutrient intake, and digestibility, microbial protein synthesis, nitrogen balance, ingestive behavior, and growth performance. Five experimental diets with $0,25 / 75,50 / 50,75 / 25$, and $100 \%$ of BRS-716 silage in compared to millet silage were evaluated. The roughage: concentrate ratio in the total dry matter (DM) of the diets was 75:25. The diets were evaluated in ten heifers with an initial body weight of $264.95 \pm 19.4 \mathrm{~kg}( \pm$ SEM), following the experimental design in two $5 \times 5$ Latin squares, simultaneously. The increase in the proportion of BRS-716 silage in the diet of crossbred dairy heifers did not change the dry matter intake (DMI), total digestible nutrients, indigestible neutral detergent fiber (iNDFI), and metabolizable energy. The means observed for DMI, and iNDFI were $7.85 \mathrm{~kg} /$ day, and $1.18 \mathrm{~kg} /$ day, respectively. For the excretion of purine derivatives, and microbial synthesis, there was no significant effect $(P>0.05)$, the mean microbial crude protein synthesis was $503.37 \mathrm{~g} /$ day. The different proportions of the BRS-716 silage, and millet silage did not change the final body weight $(P=0.89)$, weight gain $(P=0.08)$, feed efficiency $(P=0.50)$, and the body measurements of heifers $(P>0.05)$. The final body weight and average daily gain of heifers were 278.46 $\mathrm{kg}$, and $0.795 \mathrm{~kg} / \mathrm{day}$, respectively. The millet silage, and BRS-716 silage in the diet of crossbred Holstein $x$ Zebu heifers, used exclusively or combined in different proportions, allow dry matter intake, and nutrients, digestibility, nitrogen balance, microbial crude protein synthesis, ingestive behavior, and performance similar body.

\section{Introduction}

In Brazil, there is a growing need for the search for forage alternatives with high productive potential and adapted to climatic conditions, aiming at the sustainability of production systems with ruminant animals (Borges et al., 2019; Queiroz et al., 2021). In this sense, millet (Pennisetum glaucum (L.) R. Br.) is widely used in the world (Assis et al., 2017), and in Brazil, about five million hectares have been cultivated annually (Calegari et al., 2014; Carvalho et al., 2018). Due to the deep root system, capable of extracting nutrients and moisture from the soil, millet cultivation has stood out for its ability to grow under conditions of water stress (mean rainfall $400 \mathrm{~mm}$ ). Furthermore, it is adapted to environments with high temperatures (up to $40^{\circ} \mathrm{C}$ ), and presents an annual dry mass (DM) yield ranging from 10 to $20 \mathrm{t} /$ ha (Assis et al., 2017), with good nutritional value (Carvalho et al., 2018).

In 2014, EMBRAPA Corn and Sorghum (Sorghum bicolor L. Moench) launched the biomass BRS 716 sorghum for the purpose of energy cogeneration through direct biomass burning, required by the thermoelectric, and sugar-cane industries. Some studies (Almeida et al., 2019; Castro et al., 2015) demonstrated the high productive potential of BRS 716 biomass sorghum, which presents high growth characteristics (up to six meters in height) and productivity of $50 \mathrm{t} / \mathrm{ha} \mathrm{DM}$, in two cycles. Furthermore, to being tolerant to pests, diseases, water deficit, and lodging. Due to these characteristics, this species is promising as a source of nutrients for ruminant animals in several regions of the world, including those with a semi-arid climate (Ramos et al., 2021; Queiroz et al., 2021). 
Considering the important adaptability and dry mass yield of these two forage species, millet and biomass sorghum, to semi-arid conditions, it is of great relevance, the evaluation of their forage potential in the form of silage to feed ruminant animals. In addition, forage plants with high growth can rapidly change cellular components (Monção et al., 2019, 2020), modifying nutrient intake, and animal performance.

Based on the above, the objective was to compare different proportions of millet silage, and BRS-716 silage in the diet of crossbred Holstein $x$ Zebu heifers, raised in a semiarid region, on their nutrient intake, and digestibility, microbial crude protein synthesis, nitrogen balance, ingestive behavior, and growth performance.

\section{Material And Methods}

This study was conducted in the Experimental Feedlot of the State University of Montes Claros (Unimontes), Janaúba (geographical coordinates: $15^{\circ} 52^{\prime} 38$ "South, $43^{\circ} 20^{\prime} 05^{\prime \prime}$ West), Minas Gerais, Brazil.

Animals, experimental design, and treatments

The study included ten crossbred heifers $(264.95 \pm 19.4 \mathrm{~kg}$ of body weight, BW; mean \pm SD; averaging 14 mo old), with blood levels ranging from $1 / 2$ to $3 / 4$ Holstein $x$ Zebu were allotted to 10 outdoor pens ( $3 \mathrm{~m}$ feedbunk length $\times 2 \mathrm{~m}$ width) having compacted soil surface and equipped with concrete feedbunks and automatic waterers. All animals had the same origin and were selected from a 30- heifers herd. Prior to the onset of the experiment, animals were vaccinated against clostridiosis (Vac Starvac, Basso Pancotte, Nova Alvorada, RS, Brazil), injected with A, D, and E vitamins supplement (ADE Injectable and Emulsifiable Pfizer, Zoetis, Morris County, NJ, USA), and for deworming purposes also subcutaneously injected with $3.5 \%$ ivermectin (Ranger LA, Vallée S. A., São Paulo, SP, Brazil) with dosages adjusted according to BW.

The total experimental period lasted $105 \mathrm{~d}$, divided into five periods of 21 days, including a 17-d initial adaptation, and four for data collection, and samples. Animals were assigned to an experimental design was in two Latin squares $5 \times 5$, simultaneous, being five animals, five treatments and five experimental periods each. Each pen was considered as the experimental unit.

Dietary treatments were defined as follows: Treatment $1-100 \%$ of millet silage composing the roughage fraction of the diet (control); Treatment $2-75 \%$ of millet silage and $25 \%$ of BRS-716 silage; $3-50 \%$ of millet silage and $50 \%$ of BRS-716 silage; Treatment $4-25 \%$ of millet silage and $75 \%$ of BRS- 716 silage; Treatment $5-100 \%$ BRS-716 silage composing the roughage fraction of the diet.

Crops, and feeding management

The sorghum used for silage production was Sorghum bicolor (L.) Moench cv. BRS 716 biomass and the millet used for silage production was Pennisetum glaucum (L) R. Br. ADR 500, cultivated the Unimontes Experimental Farm. Sorghum was planted in an eutrophic clayey red-yellow latosol with the 
following chemical characteristics: $\mathrm{pH}$ in $\mathrm{CaCl}_{2}, 6.0 ; \mathrm{P}$ (Mehlich), $20.5 \mathrm{mg} / \mathrm{dm}^{3} ; \mathrm{K}$ (Mehlich), $90 \mathrm{mg} / \mathrm{dm}^{3}$; $\mathrm{Na}$ (Mehlich), $0.1 \mathrm{cmolc} / \mathrm{dm}^{3} ; \mathrm{Ca}^{2+}, 3.5 \mathrm{cmolc} / \mathrm{dm}^{3} ; \mathrm{Mg}^{2+}, 1.2 \mathrm{cmolc} / \mathrm{dm}^{3} ; \mathrm{Al}^{3+}, 0.0 \mathrm{cmolc} / \mathrm{dm}^{3} ; \mathrm{H}+\mathrm{Al}$ ( $0.5 \mathrm{~mol} / \mathrm{L}$ of calcium acetate), $1.4 \mathrm{cmolc} / \mathrm{dm}^{3}$; cation exchange capacity of $6.7 \mathrm{cmolc} / \mathrm{dm}^{3}$; base saturation (V) of $72 \%$. The soil was meshed and leveled mechanically using harrows attached to the tractor (Massey Ferguson 275 tractor; Massey Ferguson ${ }^{\circledR}$ AGCO, Duluth, Georgia, USA). During planting $300 \mathrm{~kg} / \mathrm{ha}$ of 04-30-10 (N-P-K) phosphate was used. Atrazine herbicide was used to control invasive plants. Millet and BRS-716 biomass sorghum were managed and harvested 122 and 164 days after planting (Queiroz et al., 2021), respectively. The dry matter yield of millet was $10.90 \mathrm{t} / \mathrm{ha}$ and that of biomass sorghum, $36.0 \mathrm{t} / \mathrm{ha}$. For millet silage and BRS-716 silage, surface type silos were used. The cost of the silage produced was $\$ 0.03$ for millet and $\$ 0.01$ for BRS-716.

The diets were formulated according to the NRC (2001) for heifers with an average of $265 \mathrm{~kg}$ of body weight (BW) and the roughage: concentrate ratio in the five experimental diets was approximately 75:25 on the basis of dry matter. The diets were supplied twice a day, at 07:00 $\mathrm{h}$ and at 14:00 $\mathrm{h}$, in a complete diet system (Total mixed ration-TMR), homogenized in the trough. The leftovers were collected and weighed daily, in the morning, before the first feeding, to adjust consumption and the quantity supplied was calculated based on the leftovers, which represented $5 \%$ of the total dry matter supplied.

Urea was used to correct the crude protein (CP) contents of the roughage fraction of the diets, using a single concentrate in the five experimental diets. To ensure the maintenance of the roughage: concentrate ratio in the total DM of the diets and that they were kept isoproteic, the DM contents, and CP of the roughages were analyzed weekly.

Feed analyses

On the 18th, 19th and 20th day of each experimental period, samples of the feed supplied, leftovers (refusals) and feces were collected in the morning and stored in a freezer, $-20^{\circ} \mathrm{C}$. Afterwards, the samples were thawed, dried in a forced-air oven at $55 \circ \mathrm{C}$ for $72 \mathrm{~h}$, and ground with a Wiley mill (MA340, Marconi, Piracicaba, Brazil) to pass a 1-mm screen. The DM of 1-mm ground samples was determined with an oven at 105.C for $24 \mathrm{~h}$ (method 934.01; AOAC, 1990), and organic matter (OM) was determined by difference after heating at $600^{\circ} \mathrm{C}$ in muffle for $2 \mathrm{~h}$ (Method 942.05; AOAC, 1990). Nitrogen content was determined using a micro Kjeldahl apparatus (TE-036/1 model, Tecnal, Piracicaba, SP, Brazil) according to (AOAC, 1990). The CP content was calculated by multiplying $N$ content by 6.25 . Ether extract (EE) was measured using a Soxhlet apparatus (TE-044 extractor, Tecnal, Piracicaba, SP, Brazil) based on extraction with petroleum ether for $6 \mathrm{~h}$ (method number 920.39; AOAC, 1990). Lignin (cellulose solubilization with $72 \% \mathrm{w} / \mathrm{w}$ sulfuric acid) and NDFap were determined according to Van Soest et al. (1991). For NDFap procedure (TE-149 fiber analyzer, Tecnal Laboratory Equipment Inc., Piracicaba, Brazil; INCT-CA F-002/1), a heat-stable a-amylase (A3306, Sigma Chemical. Co., St. Louis, MO, USA) was used without sodium sulfite nor ash- and protein-corrections. Acid detergent fiber (ADF) without ash and protein corrections was obtained as described in Goering and Van Soest (1970). The indigestible neutral detergent fiber (iNDF) (INCT-CA F-008/1) and non-fibrous carbohydrates, following the recommendations described in 
Detmann et al. (2012).The TDN was calculated according to Weiss et al. (1992). The ingredients and chemical composition of experimental diets are in Tables 1 and 2. 
Table 1

Proportion of ingredients and chemical composition of experimental diets

\begin{tabular}{|c|c|c|c|c|c|}
\hline \multirow[t]{2}{*}{ Item } & \multicolumn{5}{|c|}{ Inclusion of BRS-716 silage (\% DM) ${ }^{1}$} \\
\hline & 0 & 25 & 50 & 75 & 100 \\
\hline \multicolumn{6}{|l|}{ Proportion of ingredients in diets ( $\mathrm{g} / \mathrm{kg} \mathrm{DM}$ ) } \\
\hline Millet silage & 750 & 562 & 374 & 186,5 & 0 \\
\hline BRS-716 silage & 0 & 187 & 374 & 559,5 & 744 \\
\hline Ground corn & 160 & 160 & 160 & 160 & 160 \\
\hline Soybean meal & 80 & 80 & 80 & 80 & 80 \\
\hline Urea/Ammonium sulfate (9:1) & 5 & 6 & 7 & 9 & 11 \\
\hline Mineral mixture & 5 & 5 & 5 & 5 & 5 \\
\hline \multicolumn{6}{|l|}{ Chemical composition ( $\mathrm{g} / \mathrm{kg} \mathrm{DM}$ ) } \\
\hline Dry matter & 403.80 & 415.85 & 426.35 & 437.41 & 452.00 \\
\hline Ash & 100.13 & 98.16 & 94.74 & 91.59 & 92.64 \\
\hline Crude protein & 127.10 & 125.22 & 123.35 & 124.04 & 124.76 \\
\hline Ether extract & 28.83 & 30.97 & 33.10 & 35.38 & 37.34 \\
\hline Total carbohydrates & 752.82 & 759.11 & 764.99 & 772.22 & 776.79 \\
\hline Non-fibrous carbohydrates & 206.00 & 199.02 & 192.00 & 185.14 & 178.03 \\
\hline Neutral detergent fiber & 546.82 & 560.09 & 572.99 & 587.08 & 598.76 \\
\hline NDFap $^{2}$ & 467.33 & 481.14 & 494.62 & 509.15 & 521.56 \\
\hline $\mathrm{iNDF}^{3}$ & 213.64 & 217.90 & 222.03 & 226.61 & 230.27 \\
\hline Acid detergent fiber ${ }^{4}$ & 404.47 & 381.78 & 395.56 & 410.21 & 423.08 \\
\hline Lignin & 74.97 & 76.60 & 78.17 & 79.92 & 81.33 \\
\hline Total digestible nutrients ${ }^{5}$ & 591.64 & 590.70 & 589.51 & 589.19 & 587.18 \\
\hline Digestible energy (Mcal/kg of DM) & 3.11 & 2.94 & 2.92 & 3.05 & 3.06 \\
\hline Metabolizable energy (Mcal/kg of DM) & 2.69 & 2.51 & 2.50 & 2.63 & 2.64 \\
\hline
\end{tabular}


Mineral mixture, content per kg of product: calcium (128 g min), phosphorus (100 g min), sodium (120 g min), magnesium (15 g), sulfur (33 g), cobalt (135 mg), iron ( $938 \mathrm{mg})$, iodine (160 mg), manganese (1800 mg), selenium (34 mg), zinc (5760 mg), fluorine (1000 mg).

Table 2

Chemical composition of ingredients ( $\mathrm{g} / \mathrm{kg}$ dry matter) used in the formulation of experimental diets

\begin{tabular}{|c|c|c|c|c|}
\hline Item & $\begin{array}{l}\text { Millet } \\
\text { silage }\end{array}$ & $\begin{array}{l}\text { BRS-716 biomass } \\
\text { silage }\end{array}$ & $\begin{array}{l}\text { Ground } \\
\text { corn }\end{array}$ & Soybean meal \\
\hline Dry matter & 240.70 & 297.50 & 888.00 & 889.90 \\
\hline Ash & 106.80 & 88.50 & 29.90 & 65.60 \\
\hline Organic matter & 893.20 & 911.50 & 970.10 & 934.40 \\
\hline Crude protein & 84.80 & 61.20 & 83.50 & 463.10 \\
\hline Ether extract & 28.50 & 40.00 & 33.30 & 26.60 \\
\hline Total carbohydrates & 774.30 & 809.50 & 853.30 & 444.70 \\
\hline $\begin{array}{l}\text { Non-fibrous } \\
\text { carbohydrates }\end{array}$ & 110.10 & 73.10 & 667.50 & 207.90 \\
\hline Neutral detergent fiber & 664.20 & 736.40 & 185.80 & 236.80 \\
\hline NDFap' ${ }^{1}$ & 574.30 & 649.20 & 166.90 & 123.80 \\
\hline iNDF $^{2}$ & 258.20 & 281.50 & 92.30 & 65.30 \\
\hline Acid detergent fiber ${ }^{3}$ & 474.40 & 550.40 & 31.40 & 86.30 \\
\hline Lignin & 94.60 & 103.50 & 15.40 & 19.40 \\
\hline Total digestible nutrients ${ }^{4}$ & 518.58 & 514.69 & 861.10 & 811.60 \\
\hline
\end{tabular}

Ruminal kinetics

After pre-drying, the silage samples were ground in mills equipped with sieves with $2 \mathrm{~mm}$ sieves and placed in non-woven fabric bags in the amount of approximately $3.0 \mathrm{~g}$ of dry matter (DM)/bag, in order to maintain a ratio close to $20 \mathrm{mg} \mathrm{DM} / \mathrm{cm}^{2}$ of bag surface area. The incubation periods corresponded to times of $0,3,6,12,24,48,72,96,120$, and 144 hours, with the bags being placed at different times to be removed all at the same time from the rumen. Two cannulated crossbred steers were used, with an average body weight of $580 \pm 60 \mathrm{~kg}$ and mean age 8 years. The animals were adapted for 14 days to the diet containing $4 \mathrm{~kg}$ of concentrate ( $25 \% \mathrm{CP}$ and $65 \%$ TDN), divided into two meals, morning and afternoon, in addition to the provision of roughage based on sorghum silage (50\% millet silage and $50 \%$ 
BRS-716 silage). All the proportions of the silages used during the experiment were evaluated $(100 \%$ of millet silage; $75 \%$ of millet silage and $25 \%$ of BRS- 716 silage; $50 \%$ of millet silage and $50 \%$ of BRS-716 silage; $25 \%$ millet silage and $75 \%$ BRS-716 silage and $100 \%$ of BRS-716 silage).

After the incubation period, the nylon bags were washed in running water until it was clean, then drying. The DM determination was made in an oven regulated at $55^{\circ} \mathrm{C}$, for 72 hours. In situ dry matter degradability data were obtained from the difference observed between the weights performed before and after ruminal incubation and expressed as a percentage.

As it is a first-order asymptotic growth model, which was reparametrized by subdividing the asymptote value into two fractions, "a" and "B", the DM degradation rates were calculated using the equation proposed by Ørskov and McDonald (1979): $\mathrm{Dt}=\mathrm{a}+\mathrm{B}\left(1-\mathrm{e}^{-\mathrm{ct}}\right)$, where: $\mathrm{Dt}=$ fraction degraded over time "t" (\%), "a" = soluble fraction (\%); "B" = potentially degradable insoluble fraction (\%); "c" = rate of degradation of fraction "B" (/h); and "t" = time (h).

The degradation of NDF was interpreted using the model of Mertens and Loften (1980): Rt $=\mathrm{B}^{*} \mathrm{e}^{-\mathrm{ct}}+\mathrm{l}$, where: $\mathrm{Rt}=$ fraction degraded in time "t" (\%) ; I = undegradable fraction; and "B", c"'" and "t" as defined above. Fractions were standardized according to the proposition by Waldo et al. (1972), according to equations: $B_{P}=B /(B+I) * 100 ; I_{P}=I /(B+I) * 100 ; I=100-(a+b)$, where: $B_{P}=$ standardized potentially degradable fraction (\%); $I_{P}=$ standardized non-degradable fraction (\%); $B$ and $I=$ as defined above.

The nonlinear parameters "a", "b" and "c" were estimated using least squares iterative procedures. The effective degradability (ED) of DM in the rumen were calculated using the model: $E D=a+(B \times c / c+k)$, where: $k$ corresponds to the rate of passage of particles in the rumen, of according to the AFRC (1993). For the ED of NDF, the model was used: $E D=B_{P}{ }^{*} c /(c+k)$, where $B_{P}$ is the standardized potentially degradable fraction (\%).

Intake and digestibility of nutrients

Feed intake was monitored from d 1 to 105 . Feed delivery was adjusted daily and fed to appetite allowing ad libitum intake and orts below $5 \%$ of daily intake. Feed bunks were cleaned and orts weighed daily before morning feeding. Feed offered and orts were sampled weekly and frozen at $-20 \circ C$ for further DM determination. The DMI was calculated daily per pen by subtracting orts from offered feed (on a DM basis). To estimate the daily of metabolizable energy intake (MEI) was taken into account the DMI. The fecal dry matter production was estimated using indigestible neutral detergent fiber (iNDF) as an internal indicator. Samples of feed, leftovers and feces, ground in a knife mill with a sieve with $2 \mathrm{~mm}$ diameter sieves, were incubated in two crossbred adult cattle, weighing $480 \pm 30 \mathrm{~kg}$, mean age 8 years, cannulated in the rumen, during 288 hours, following the methodology (INCT-CA F-009/1) presented by Detmann et al. (2012). The digestibility coefficient of all nutrients was calculated using the following equation: [quantity ingested - quantity excreted in the feces]/quantity ingested. Based on the digestibility coefficients, the value of total digestible nutrients was calculated. 
Nitrogen balance and microbial synthesis

Spot urine samples were obtained on the 18th day of each experimental period, approximately four hours after feeding in the morning, during spontaneous urination. $10 \mathrm{~mL}$ aliquots of this sample were filtered and immediately diluted in $40 \mathrm{~mL}$ of $0.036 \mathrm{~N} \mathrm{H}_{2} \mathrm{SO}_{4}$ for further analysis of creatinine. These aliquots were stored in plastic flasks, identified and frozen for further analysis and quantification of urea, total nitrogen, creatinine, uric acid and allantoin.

Blood samples were collected on the first and last day of each experimental period, via puncture of the jugular vein, using $5 \mathrm{~mL}$ test tubes (Vacutainer ${ }^{\mathrm{T}}$ ) with EDTA (anticoagulant). Immediately, centrifugation was carried out at 5,000 rpm for 15 minutes and, subsequently, plasma samples were taken, which were packed in eppendorf and stored at $-15^{\circ} \mathrm{C}$ for further analysis of urea.

The concentrations of urea, creatinine and uric acid in the urine and urea in the plasma were estimated using commercial kits (Bioclin, Belo Horizonte, Minas Geras, Brazil). The conversion of urea values into urea nitrogen was performed by multiplying the values obtained by the factor 0.4667 .

The urinary contents of allantoin and uric acid were estimated by colorimetric methods, as specified by Chen and Gomes (1992), and the total nitrogen content estimated by the Kjeldhal method (Detmann et al., 2012). The balance of nitrogen compounds (Nitrogen balance; $g /$ day) was calculated as: $N$ retained $(g)=$ $\{\mathrm{N}$ ingested (g) - $\mathrm{N}$ fecal (g) - N urine (g)\}, where: Nitrogen balance = nitrogen retained in the animal's organism; $\mathrm{N}$ ingested = nitrogen ingested by the animal; $\mathrm{N}$ fecal = nitrogen excreted in feces and $\mathrm{N}$ urine = nitrogen excreted in urine. The excretion of creatinine $(\mathrm{mg} / \mathrm{kg} \mathrm{BW})$ used to estimate the urinary volume through the spot samples was obtained for each animal, according to the equation described by Chizzotti et al. (2008): $E C=\{32.27-0.01093 \times B W\}$, where: $E C=$ daily excretion of creatinine $(\mathrm{mg} / \mathrm{kg} \mathrm{BW})$. Since, in growing animals, the percentage of muscle tissue varies according to body weight and, consequently, the excretion of creatinine $(\mathrm{mg} / \mathrm{kg}$ of $\mathrm{BW}$ ) can be altered. The total daily urinary volume was estimated by dividing the daily urinary excretions of creatinine by the observed values of creatinine concentration in the urine.

The excretion of total purines was estimated by the sum of the amounts of allantoin and uric acid excreted in the urine and the amount of absorbed purines ( $\mathrm{mmol} /$ day), by the excretion of total purines (mmol/day), by means of equation proposed by Verbic et al. (1990):AP $=\{($ total purines $-0.385 \times B W$ $\left.\left.{ }^{0.75}\right) / 0.85\right\}$, where: $A P=$ absorbed purines $(\mathrm{mmol} /$ day $) ; 0.85=$ recovery of purines absorbed as purine derivatives in the urine; and $0.385=$ endogenous excretion of purine derivatives in the urine $(\mathrm{mmol})$ per unit of metabolic size (0.75 BW).

To estimate microbial protein production (MCP), purine bases (mmol/day) were used as a microbial indicator, whose quantification was performed according to the technique of Chen and Gomes (1992): $\operatorname{MCP}(\mathrm{g} /$ day $)=\{(70 \times \mathrm{AP}) /(0.85 \times 0.116 \times 1000)\}$, assuming the value of 70 for the nitrogen content in the purines $(\mathrm{mg} / \mathrm{mmol}) ; 0.83$ for intestinal digestibility of microbial purines and 0.116 for the $\mathrm{N}_{\text {PURINE: }} \mathrm{N}$ TOTAL ratio in bacteria. 
The microbial crude protein synthesis efficiency was calculated as follows: microbial crude protein synthesis efficiency $=\{(0.629 \times \mathrm{AP}) \times 6.25) / \mathrm{TDN}$ intake $\}$, where: $\mathrm{AP}=$ absorbed purines $(\mathrm{mmol} / \mathrm{day})$; TDNI - total digestible nutrients intake; 0.629 represents the absorbed purine without considering the contribution of the endogenous fraction.

Determination of ingestive behavior

Ingestive behavior followed the method described in Monção et al. (2020). Visual observations for each pen $(n=1)$ were recorded every 5 min during the 24-h cycle on d 19 and 20 of each experimental period. Different groups of two observers each were assigned every 5-h interval. Each observer was responsible for recording the ingestive behavior of animals in 5 pens ( 5 animals). Pen observations were conducted sequentially, always following the same order per observer. Eating, ruminating, and total chewing times $(\mathrm{min} / \mathrm{d})$ were calculated by the number of observations multiplied by 5 . Total chewing time was the sum of eating and ruminating times. Ingestive variables were also expressed as $\mathrm{min} / \mathrm{kg} \mathrm{DMI}$. To allow this, DMI was determined by subtracting orts from offered feed (on DM basis).

Growth performance, and biometric measurements

At the beginning and at the end ( 21 th) of each experimental period, after a 16-hour fast of solids, the body weight of animals was evaluate, we used a mechanical scale (mechanical scale, Valfran, Votuporanga, São Paulo, Brazil). Moreover, measurements were made of the thoracic perimeter, withers and croup height and body length. The measurements were made according to the methodology of Hoffman (1997), with the animals in a forced station, that is, front and rear members perpendicular on a flat floor, forming a rectangular parallelogram. Feed efficiency was calculated by dividing weight gain (kg/day) with DM intake (kg/day).

Statistical Analyses

Data were evaluated by analysis of variance using the MIXED procedure of SAS, version 9.0 (SAS Inst. Inc., Cary, NC, USA). Data normality (Shapiro-Wilk test at $5 \%$ probability) was verified by the UNIVARIATE procedure in SAS. The statistical model used for analyses was $Y_{k(i j)}=\mu+P_{i}+A_{j}+Q_{l}+T_{k(i j l)}+P I+Q I+e$ $k(i j)$, where $Y_{k(j i j)}$ is the observation concerning the treatment " $k$ ", within period I, animal $j$ and Latin square (Q) $\mathrm{I} ; \mu$ is a constant associated with all observations; $\mathrm{Pi}$ is the effect of period $\mathrm{i}$, with $\mathrm{i}=1,2,3$ and 4 ; $\mathrm{Aj}$ is the animal effect $j$, with $j=1,2,3,4$, and 5 ; Ql is the Latin square effect $\left.l ; T_{k(j i)}\right)$ is the treatment effect $k$, with $\mathrm{k}=1,2,3,4$, and 5 ; PI is the initial body weight as a covariable and e $\mathrm{k}$ (ijl) is the experimental error associated with all observations $\left(\mathrm{Y}_{\mathrm{k}(\mathrm{ijl})}\right)$, which is independent and by hypothesis has a normal distribution with mean zero and variance $\delta_{2}$. The treatments $\left(T_{k(j \mathrm{jl})}\right)$ were considered to be fixed effects; animals $(\mathrm{Aj})$, experimental period $(\mathrm{Pi})$, initial body weight and the error term $\left(\mathrm{e}_{\mathrm{k}(\mathrm{ijl})}\right)$ were random effects.

The ruminal degradability of DM and NDF was conducted in a randomized complete block design in subdivided plots, with five treatments (plots), 10 incubation times (subplots) and five replications. The variation of the animals' body weight was the blocking factor. Ruminal fermentation variables were 
analyzed as repeated measures using the PROC MIXED, according to the following model: $Y_{\mathrm{ijk}} \mathrm{m}=\mu+A_{i}$ $+P_{j}+B_{k}+a_{k l}+\omega_{i j k l}+T m+T \times A_{m i}+\varepsilon_{i j k l m}$

where $\omega \mathrm{i}_{\mathrm{jkl}} \approx \mathrm{N}\left(0, \mathrm{a}^{2}{ }_{\omega}\right)$ and $\varepsilon_{\mathrm{ijk} / \mathrm{m}} \approx \mathrm{MVN}(0, \mathrm{R})$, and $\mathrm{Y}_{\mathrm{ijklm}}=$ observation on animal $\mathrm{l}$, given treatment $\mathrm{i}$, at period $j$, in block $k$, in time $m ; \mu, A_{i}, P_{j}, B_{k}$, and $a_{k l}$ were previously defined; $\omega_{i j k l}=$ the residual error associated with cows within experimental period; $T_{m}=$ the fixed effect of the sampling time ( $m=1$ to 10$)$; $\mathrm{T} \times \mathrm{A}_{\mathrm{mi}}=$ the fixed interaction effect between the time and treatment; $\varepsilon_{\mathrm{ijklm}}=$ random residual error; $\mathrm{a}^{2}{ }_{\omega}=$ the estimated variance associated with experimental units (cows within period); $M V N=$ multivariate normal; and $\mathrm{R}=$ the variance-covariance matrix of residuals due to repeated measurements. Variance covariance matrices were evaluated [UN, UN1, CS, CSH, AR(1), ARH(1), TOEP, TOEPH, FA(1), and ANTE(1)] and chosen by the Bayesian method. The covariance matrix that best fit the data according to the corrected Bayesian information criterion (BIC) was variance components (UN). When determined to be significant by the $F$ test, the means of the treatments were compared by decomposing the sum of squares into orthogonal linear contrasts and quadratic effects at $5 \%$ probability, with subsequent adjustments to the regression equations. Outliers were identified and deleted if the absolute values of Studentized residuals exceeded \pm 3 . The mean values were considered to be different when $p<0.05$.

\section{Results}

Ruminal kinetics

The increase in the proportion of BRS-716 silage linearly reduced the readily soluble fraction (fraction "a"), potential degradability and effective degradability of DM at different passage rates 2,5 and $8 \% / h(P<$ 0.01 ) and linearly increased the indegradable fraction of DM (Table 3). For each percentage unit of inclusion of the BRS-716 silage, there was a reduction of $0.10,0.11,0.06,0.07$, and 0.08 percentage points $(\mathrm{pp})$ respectively. 
Table 3

Ruminal kinetics of dry matter and fibrous fraction of different proportions of millet silage and BRS-716 silage

\begin{tabular}{|c|c|c|c|c|c|c|c|c|}
\hline \multirow[t]{2}{*}{ Item (\%) } & \multicolumn{5}{|c|}{ Inclusion of BRS-716 silage (\% DM) } & \multirow[t]{2}{*}{$\mathrm{SEM}^{14}$} & \multicolumn{2}{|c|}{ p-value ${ }^{15}$} \\
\hline & 0 & 25 & 50 & 75 & 100 & & Linear & Quad \\
\hline & \multicolumn{8}{|c|}{ Dry matter, \% } \\
\hline Fraction "a"1 & 30.50 & 29.78 & 29.22 & 21.02 & 21.82 & 0.48 & $<0.01$ & 0.02 \\
\hline Fraction "b" & 39.30 & 36.21 & 39.48 & 38.35 & 37.84 & 1.80 & 0.89 & 0.91 \\
\hline Degradation rate "c", $(\% / h)^{2}$ & 1.00 & 1.00 & 1.00 & 2.00 & 2.00 & 0.01 & $<0.01$ & 0.05 \\
\hline Potential degradability ${ }^{3}$ & 69.80 & 65.99 & 68.70 & 59.36 & 59.67 & 1.89 & $<0.01$ & 0.60 \\
\hline Indegradable fraction ${ }^{4}$ & 30.20 & 31.20 & 34.01 & 40.64 & 40.33 & 1.89 & $<0.01$ & 0.60 \\
\hline $\begin{array}{l}\text { Effective degradability - } 2 \% \\
5\end{array}$ & 45.85 & 43.92 & 42.96 & 40.75 & 40.31 & 0.57 & $<0.01$ & 0.43 \\
\hline $\begin{array}{l}\text { Effective degradability - } \\
5 \% 6\end{array}$ & 38.57 & 37.27 & 36.21 & 32.50 & 32.40 & 0.53 & $<0.01$ & 0.92 \\
\hline $\begin{array}{l}\text { Effective degradability - } \\
8 \% 7\end{array}$ & 35.98 & 34.83 & 33.91 & 29.13 & 29.24 & 0.49 & $<0.01$ & 0.48 \\
\hline \multicolumn{9}{|c|}{ Neutral detergent fiber, $\%$} \\
\hline Fraction “Bp” 8 & 61.38 & 59.87 & 64.34 & 57.32 & 52.07 & 2.11 & $<0.01$ & 0.03 \\
\hline Degradation rate "c" $(\% / \mathrm{h})^{9}$ & 2.00 & 1.00 & 1.00 & 3.00 & 3.00 & 0.01 & $<0.01$ & $\dot{0} 01$ \\
\hline $\mathrm{Ip}^{\mathrm{C}}, \% 10$ & 38.62 & 40.14 & 35.66 & 42.68 & 47.93 & 2.11 & $<0.01$ & 0.03 \\
\hline
\end{tabular}

Ip - standardized indigestible fraction; 2,5 , and $8 \%$ - passage rate according to the AFRC (1993)

Regression equation: ${ }^{1} \hat{Y}=31.69-0.1045^{\star} X, R^{2}=0.79 ;{ }^{2} \hat{Y}=0.80+0.012^{\star} X, R^{2}=0.75 ;{ }^{3} \hat{Y}=70.08-$ $0.1{ }^{\star} X, R^{2}=0.74 ;{ }^{4} \hat{Y}=29.33+0.12 \star X, R^{2}=0.89 ;{ }^{5} \hat{Y}=45.60-0.06 * X, R^{2}=0.97 ;{ }^{6} \hat{Y}=38.81-0.07 * X, R^{2}$ $=0.92 ;{ }^{7} \hat{Y}=36.45-0.08 * X, R^{2}=0.88 ;{ }^{8} \hat{Y}=60.52+0.1321 * X-0.0022 * X^{2}, R^{2}=0.82 ;{ }^{9} \hat{Y}=1.77-0.03^{*} X$ $+0.0005^{*} X^{2}, R^{2}=0.68 ;{ }^{10} \hat{Y}=39.48-0.13^{*} X+0.002 * X^{2}, R^{2}=0.82 ;{ }^{11} \hat{Y}=26.32-0.12 * X+0.002 * X^{2}, R^{2}=$ $0.61 ;{ }^{12} \hat{Y}=14.57-0.11 * X+0.002 * X^{2}, R^{2}=0.71 ;{ }^{13} \hat{Y}=10.11-0.09 * X+0.0014 * X^{2}, R^{2}=0.74$, where $\hat{Y}$ is the predicted value for each variable and $X$ is the inclusion of BRS-716 silage. $R^{2}$ is the coefficient of determination. * significant by the $t$ test $(p<0.05)$.

${ }^{14}$ SEM - Standard error of the mean. Five observations (pen) per treatment.

${ }^{15}$ p- Probability. 


\begin{tabular}{|c|c|c|c|c|c|c|c|c|}
\hline \multirow[t]{2}{*}{ Item (\%) } & \multicolumn{5}{|c|}{ Inclusion of BRS-716 silage (\% DM) } & \multirow[t]{2}{*}{ SEM $^{14}$} & \multicolumn{2}{|c|}{ p-value ${ }^{15}$} \\
\hline & 0 & 25 & 50 & 75 & 100 & & Linear & Quad \\
\hline $\begin{array}{l}\text { Effective degradability - } \\
2 \% 11\end{array}$ & 27.39 & 22.83 & 22.96 & 31.10 & 30.40 & 1.20 & $<0.01$ & $\hat{0} .01$ \\
\hline $\begin{array}{l}\text { Effective degradability }-5 \% \\
12\end{array}$ & 15.28 & 11.96 & 11.72 & 18.64 & 19.02 & 1.03 & $<0.01$ & $\grave{0} 01$ \\
\hline $\begin{array}{l}\text { Effective degradability - 8\% } \\
13\end{array}$ & 10.63 & 8.11 & 7.87 & 13.34 & 13.89 & 0.85 & $<0.01$ & $<.01$ \\
\hline \multicolumn{9}{|c|}{ Ip - standardized indigestible fraction; 2,5 , and $8 \%$ - passage rate according to the AFRC (1993) } \\
\hline \multicolumn{9}{|c|}{ 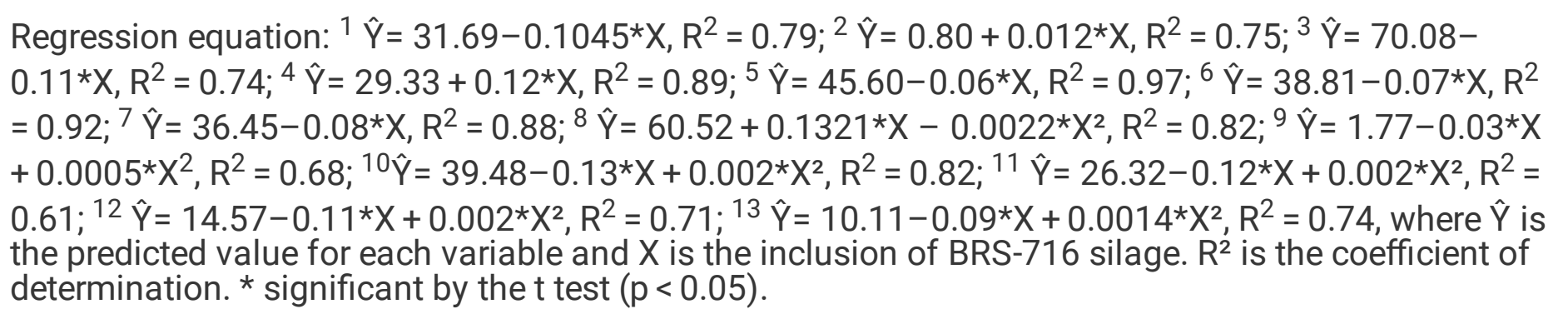 } \\
\hline \multicolumn{9}{|c|}{${ }^{14}$ SEM - Standard error of the mean. Five observations (pen) per treatment. } \\
\hline robability. & & & & & & & & \\
\hline
\end{tabular}

For the standardized degradable potential insoluble fraction (Fraction $\mathrm{Bp}$ ), degradation rate of the fraction Bp " $\mathrm{C}$ ", standardized indigestible fraction (IP) and effective degradability ( $k=2,5$, and $8 \% / h)$ of the neutral detergent fiber, the means adjusted to the quadratic regression model. The maximum point of the fraction $\mathrm{Bp}$ it was verified in the inclusion of $30.02 \%$ of BRS-716 silage. The minimum point for the degradation rate of the fraction $\mathrm{Bp}$ " $\mathrm{C}$ ", and the indegradable fraction of the fibrous fraction was verified in the proportion of 30.0 and $32.5 \%$ inclusion of BRS-716 silage, respectively.

Intake and digestibility of nutrients

Diets with different proportions of BRS-716 silage and millet silage for crossbred dairy heifers did not modify the dry matter intake (DMI), crude protein intake, NDF intake, ether extract intake, non-fibrous carbohydrates intake, total digestible nutrients intake, indigestible neutral detergent fiber intake (iNDFI), and metabolizable energy intake (Table 4). The means observed for DMI and iNDFI were $7.85 \mathrm{~kg} / \mathrm{day}$ and $1.18 \mathrm{~kg} /$ day, respectively. 
Table 4

Nutrient intake and digestibility in crossbred Holstein $x$ Zebu heifers fed diets containing different proportions of millet silage and BRS-716 silage

\begin{tabular}{|c|c|c|c|c|c|c|c|c|}
\hline \multirow[t]{2}{*}{ Item } & \multicolumn{5}{|c|}{ Inclusion of BRS-716 silage (\% DM) } & \multirow[t]{2}{*}{ SEM $^{4}$} & \multicolumn{2}{|c|}{ p-value ${ }^{5}$} \\
\hline & 0 & 25 & 50 & 75 & 100 & & Linear & Quad \\
\hline & \multicolumn{8}{|c|}{ Intake, kg/day } \\
\hline Dry matter & 7.59 & 7.94 & 7.80 & 8.30 & 7.66 & 0.52 & 0.99 & 0.99 \\
\hline Crude protein & 0.96 & 0.99 & 0.96 & 1.03 & 0.96 & 0.07 & 0.98 & 0.99 \\
\hline NDFap & 4.15 & 4.45 & 4.47 & 4.65 & 4.59 & 0.52 & 0.13 & 0.68 \\
\hline Ether extract & 0.22 & 0.25 & 0.26 & 0.26 & 0.29 & 0.01 & 0.53 & 0.43 \\
\hline Non-fibrous carbohydrate & 1.56 & 1.58 & 1.50 & 1.65 & 1.36 & 0.17 & 0.15 & 0.99 \\
\hline Total digestible nutrients & 5.47 & 5.28 & 5.21 & 5.77 & 5.32 & 0.38 & 0.87 & 0.95 \\
\hline iNDF $^{1}$ & 1.22 & 1.10 & 1.05 & 1.34 & 1.18 & 0.11 & 0.63 & 0.50 \\
\hline \multirow[t]{2}{*}{ ME, Mcal/day } & 20.92 & 19.95 & 19.73 & 21.97 & 20.26 & 1.47 & 0.88 & 0.86 \\
\hline & \multicolumn{8}{|c|}{ Intake, \% body weight } \\
\hline Dry matter & 3.00 & 3.14 & 3.06 & 3.33 & 3.09 & 0.13 & 0.99 & 0.99 \\
\hline Crude protein & 0.36 & 0.38 & 0.36 & 0.38 & 0.36 & 0.01 & 0.99 & 0.99 \\
\hline NDFap ${ }^{2}$ & 1.57 & 1.69 & 1.69 & 1.73 & 1.74 & 0.11 & 0.12 & 0.80 \\
\hline Ether extract & 0.08 & 0.09 & 0.10 & 0.10 & 0.11 & 0.01 & 0.13 & 0.28 \\
\hline Non-fibrous carbohydrate & 059 & 0.60 & 0.57 & 0.61 & 0.52 & 0.07 & 0.35 & 0.99 \\
\hline Total digestible nutrients & 2.11 & 2.08 & 2.03 & 2.29 & 2.16 & 0.11 & 0.38 & 0.78 \\
\hline \multirow[t]{2}{*}{ iNDF } & 0.47 & 0.42 & 0.40 & 0.55 & 0.50 & 0.04 & 0.21 & 0.31 \\
\hline & \multicolumn{8}{|c|}{ Apparent total-tract digestibility $(\mathrm{g} / \mathrm{kg})$} \\
\hline Dry matter & 725.2 & 754.9 & 742.8 & 739.1 & 744.5 & 18.3 & 0.55 & 0.09 \\
\hline Crude protein & 759.7 & 774.5 & 777.9 & 780.1 & 768.0 & 12.3 & 0.57 & 0.23 \\
\hline Ether extract ${ }^{3}$ & 909.2 & 921.0 & 939.9 & 927.1 & 904.7 & 8.1 & 0.13 & 0.04 \\
\hline NDFap & 661.7 & 549.9 & 594.4 & 559.7 & 601.1 & 8.2 & 0.66 & 0.45 \\
\hline Non-fibrous carbohydrate & 851.0 & 873.8 & 897.7 & 872.7 & 841.1 & 24.83 & 0.83 & 0.10 \\
\hline
\end{tabular}

iNDF - Indigestible neutral detergent fiber; NDFap - Neutral detergent fiber corrected for ash and protein 


\begin{tabular}{|c|c|c|c|c|c|c|c|c|}
\hline \multirow[t]{2}{*}{ Item } & \multicolumn{5}{|c|}{ Inclusion of BRS-716 silage (\% DM) } & \multirow[t]{2}{*}{ SEM $^{4}$} & \multicolumn{2}{|c|}{ p-value ${ }^{5}$} \\
\hline & 0 & 25 & 50 & 75 & 100 & & Linear & Quad \\
\hline Total digestible nutrients & 688.0 & 650.1 & 649.0 & 672.9 & 676.0 & 18.5 & 0.98 & 0.13 \\
\hline
\end{tabular}

Regression equation: ${ }^{3} \hat{Y}=906.6+1.13^{*} X-0.01 * X^{2}, R^{2}=0.89$, where $\hat{Y}$ is the predicted value for each variable and $X$ is the inclusion of BRS-716 silage. $R^{2}$ is the coefficient of determination. * significant by the $t$ test $(p<0.05)$.

SEM - Standard error of the mean. Five observations (pen) per treatment.

p- Probability.

The DMI and nutrients when expressed as a percentage of BW, was not modified due to experimental diets, mean of $3.12 \%$ BW for DMI. There was a quadratic effect on the digestibility of the ether extract, with an increase in the proportion of BRS-716 silage in the diet. The greater digestibility of the ether extract was verified in the proportion of $56.5 \%$ inclusion of BRS-716 silage. As for the other variables related to apparent digestibility, no differences were found between the diets $(P>0.05)$.

Nitrogen balance and microbial synthesis

The different proportions of BRS-716 silage and millet silage in the diet of crossbred dairy heifers did not change the daily nitrogen intake ( $\mathrm{N}$; mean of $132.42 \mathrm{~g}$ ). For the $\mathrm{N}$ excreted in the feces, a linear reduction from $0.03 \mathrm{~g}$ to $1 \%$ inclusion of BRS-716 silage was observed (Table 5). 
Table 5

Nitrogen balance and microbial synthesis in crossbred Holstein $x$ Zebu heifers fed diets containing different proportions of millet silage and BRS-716 silage

\begin{tabular}{|c|c|c|c|c|c|c|c|c|}
\hline \multirow[t]{2}{*}{ Item } & \multicolumn{5}{|c|}{ Inclusion of BRS-716 silage (\% DM) } & \multirow[t]{2}{*}{ SEM } & \multicolumn{2}{|c|}{ p-value } \\
\hline & 0 & 25 & 50 & 75 & 100 & & Linear & Quad \\
\hline & \multicolumn{8}{|c|}{ Balance of nitrogen compounds } \\
\hline N-ingested, g/day & 137.7 & 134.1 & 135.9 & 138.5 & 115.9 & 10.1 & 0.22 & 0.32 \\
\hline $\mathrm{N}$-fecal, g/day & 16.7 & 16.5 & 15.5 & 14.4 & 13.8 & 0.6 & $<0.01$ & 0.77 \\
\hline N-urine, g/day & 15.6 & 14.0 & 11.9 & 11.8 & 12.8 & 1.1 & 0.84 & 0.37 \\
\hline $\begin{array}{l}\text { Nitrogen balance, } \\
\text { g/day }\end{array}$ & 105.3 & 103.6 & 108.5 & 112.3 & 89.2 & 9.2 & 0.42 & 0.25 \\
\hline $\mathrm{N}$-fecal, \% NI & 13.6 & 13.7 & 14.6 & 11.9 & 13.3 & 1.6 & 0.62 & 0.86 \\
\hline $\mathrm{N}$-urine, \% NI & 14.0 & 10.4 & 11.2 & 10.8 & 13.4 & 1.8 & 0.86 & 0.36 \\
\hline Nitrogen balance, \% NI & 72.4 & 77.2 & 74.3 & 77.2 & 73.3 & 2.5 & 0.99 & 0.47 \\
\hline $\begin{array}{l}\text { Plasma urea nitrogen, } \\
\mathrm{mg} / \mathrm{dL}\end{array}$ & 47.7 & 51.2 & 56.5 & 57.7 & 51.9 & 3.7 & 0.21 & 0.10 \\
\hline \multirow{2}{*}{$\begin{array}{l}\text { Urinary nitrogen, } \\
\mathrm{mg} / \mathrm{dL}\end{array}$} & 0.8 & 0.8 & 1.0 & 0.9 & 0.8 & 0.1 & 0.82 & 0.05 \\
\hline & \multicolumn{8}{|c|}{ Microbial production } \\
\hline Allantoin (mmol/day) & 104.02 & 100.64 & 115.59 & 102.90 & 109.21 & 14.24 & 0.78 & 0.87 \\
\hline Uric acid (mmol/day) & 13.95 & 11.66 & 16.39 & 12.16 & 13.43 & 1.98 & 0.93 & 0.80 \\
\hline $\begin{array}{l}\text { Purine derivatives } \\
\text { (mmol/day) }\end{array}$ & 117.98 & 112.30 & 131.98 & 115.07 & 122.63 & 14.67 & 0.79 & 0.85 \\
\hline $\begin{array}{l}\text { Allantoin: purine } \\
\text { derivatives }\end{array}$ & 86.65 & 89.34 & 86.75 & 90.12 & 87.88 & 2.14 & 0.63 & 0.63 \\
\hline $\begin{array}{l}\text { Absorbed purine, } \\
\text { g/day }\end{array}$ & 108.62 & 101.80 & 125.03 & 105.01 & 113.42 & 17.15 & 0.81 & 0.84 \\
\hline $\begin{array}{l}\text { Microbial nitrogen } \\
\text { (g/day) }\end{array}$ & 78.97 & 74.02 & 90.90 & 76.34 & 82.46 & 12.46 & 0.81 & 0.84 \\
\hline $\begin{array}{l}\text { Microbial crude } \\
\text { protein, g/day }\end{array}$ & 493.57 & 462.60 & 568.13 & 477.15 & 515.40 & 77.93 & 0.81 & 0.84 \\
\hline
\end{tabular}

$\mathrm{N}$ - Nitrogen; MCP - Microbial crude protein; TDN - Total digestible nutrients; OM - Organic matter.

Regression equation: ${ }^{1} \hat{Y}=16.98-0.031 * X, R^{2}=0.96$, where $\hat{Y}$ is the predicted value for each variable and $X$ is the inclusion of BRS-716 silage. $R^{2}$ is the coefficient of determination. * significant by the $t$ test $(p<0.05)$. SEM - Standard error of the mean; $p$ - Probability. 


\begin{tabular}{|c|c|c|c|c|c|c|c|c|}
\hline \multirow[t]{2}{*}{ Item } & \multicolumn{5}{|c|}{ Inclusion of BRS-716 silage (\% DM) } & \multirow[t]{2}{*}{ SEM } & \multicolumn{2}{|l|}{ p-value } \\
\hline & 0 & 25 & 50 & 75 & 100 & & Linear & Quad \\
\hline $\begin{array}{l}\text { Microbial efficiency, g } \\
\text { MCP/kg TDN }\end{array}$ & 137.18 & 107.38 & 156.22 & 117.09 & 134.46 & 20.53 & 0.94 & 0.93 \\
\hline $\begin{array}{l}\text { Microbial efficiency, g } \\
\text { N/kg digested OM }\end{array}$ & 206.12 & 192.03 & 193.09 & 205.50 & 170.84 & 14.17 & 0.21 & 0.57 \\
\hline \multicolumn{9}{|c|}{ N - Nitrogen; MCP - Microbial crude protein; TDN - Total digestible nutrients; OM - Organic matter. } \\
\hline \multicolumn{9}{|c|}{$\begin{array}{l}\text { Regression equation: }{ }^{1} \hat{Y}=16.98-0.031 * X, R^{2}=0.96 \text {, where } \hat{Y} \text { is the predicted value for each variable } \\
\text { and } X \text { is the inclusion of BRS-716 silage. } R^{2} \text { is the coefficient of determination. }{ }^{*} \text { significant by the } t \\
\text { test }(p<0.05) \text {. SEM - Standard error of the mean; } p \text { - Probability. }\end{array}$} \\
\hline
\end{tabular}

For the retained nitrogen (Nitrogen balance), expressed in grams and percentage of the nitrogen ingested, plasma urea nitrogen and urinary nitrogen, there was no differences between experimental diets, with the means of $104.84 \mathrm{~g} /$ day, $75.18 \%, 17.66 \mathrm{mg} / \mathrm{dL}$, and $0.86 \mathrm{mg} / \mathrm{dL}$, respectively. Regarding the excretion of purine derivatives and microbial synthesis, there was no significant effect $(P>0.05)$ due to diets with different proportions of BRS-716 silage and millet silage.

Ingestive behavior

The feeding behavior of crossbred Holstein $x$ Zebu heifers was not influenced with the different proportions of BRS-716 silage and millet silage in the diet (Table 6). The means of feeding, rumination and idle time were 369.1, 495.5 and 575.4 minutes/day, respectively. 
Table 6

Feeding behavior in crossbred Holstein x Zebu heifers fed diets containing different proportions of millet silage and BRS-716 silage

\begin{tabular}{|c|c|c|c|c|c|c|c|c|}
\hline \multirow[t]{2}{*}{ Item } & \multicolumn{5}{|c|}{ Inclusion of BRS-716 silage (\% DM) } & \multirow[t]{2}{*}{ SEM } & \multicolumn{2}{|l|}{ p-value } \\
\hline & 0 & 25 & 50 & 75 & 100 & & Linear & Quad \\
\hline & Eating & & & & & & & \\
\hline $\min /$ day & 377.0 & 364.0 & 366.0 & 372.0 & 366.5 & 8.4 & 0.62 & 0.55 \\
\hline \multirow[t]{2}{*}{$\min / \mathrm{kg} \mathrm{DM}$} & 55.9 & 52.5 & 58.3 & 50.2 & 54.5 & 5.9 & 0.78 & 0.95 \\
\hline & \multicolumn{5}{|c|}{ Rumination } & & & \\
\hline $\min /$ day & 483.0 & 478.5 & 489.0 & 535.5 & 491.5 & 13.9 & 0.10 & 0.41 \\
\hline \multirow[t]{2}{*}{$\mathrm{min} / \mathrm{kg} \mathrm{DM}$} & 72.3 & 68.8 & 76.7 & 72.3 & 73.4 & 8.3 & 0.82 & 0.91 \\
\hline & Idle & & & & & & & \\
\hline \multirow[t]{2}{*}{$\min /$ day } & 580.0 & 597.5 & 585.0 & 532.5 & 582.0 & 15.7 & 0.22 & 0.68 \\
\hline & \multicolumn{5}{|l|}{ Chewing } & & & \\
\hline number/bolus & 55.9 & 57.7 & 59.4 & 58.3 & 56.9 & 1.9 & 0.66 & 0.19 \\
\hline \multirow[t]{2}{*}{$\min /$ day } & 511.6 & 1113.7 & 1480.2 & 1121.0 & 1087.7 & 328.9 & 0.27 & 0.11 \\
\hline & \multicolumn{5}{|c|}{ Number of periods ( $n /$ day) } & & & \\
\hline Eating & 10.9 & 10.1 & 10.7 & 10.0 & 10.2 & 0.7 & 0.49 & 0.78 \\
\hline Ruminating & 13.6 & 13.5 & 13.7 & 13.0 & 13.7 & 0.7 & 0.89 & 0.78 \\
\hline \multirow[t]{2}{*}{ Idle } & 19.6 & 20.0 & 19.6 & 19.0 & 19.3 & 0.8 & 0.52 & 0.89 \\
\hline & \multicolumn{5}{|c|}{ Time spent per period (min) } & & & \\
\hline Eating & 2198.7 & 2306.0 & 2181.7 & 2410.2 & 2348.8 & 147.0 & 0.39 & 0.97 \\
\hline Ruminating & 2146.6 & 2154.0 & 2203.1 & 2490.5 & 2211.9 & 106.2 & 0.17 & 0.40 \\
\hline \multirow[t]{2}{*}{ Idle } & 1790.8 & 1815.6 & 1810.7 & 1696.9 & 1874.7 & 76.7 & 0.84 & 0.49 \\
\hline & \multicolumn{5}{|c|}{ Feed efficiency } & & & \\
\hline $\mathrm{g} \mathrm{DM} / \mathrm{h}$ & 20.4 & 22.2 & 21.6 & 22.9 & 21.9 & 1.4 & 0.41 & 0.49 \\
\hline \multirow[t]{2}{*}{ g NDFap/h } & 5.9 & 6.0 & 6.8 & 7.7 & 7.2 & 0.7 & 0.07 & 0.69 \\
\hline & \multicolumn{5}{|c|}{ Rumination efficiency } & & & \\
\hline Boluses/day & 36036.8 & 35574.9 & 36721.0 & 40039.8 & 37430.3 & 1558.6 & 0.15 & 0.71 \\
\hline
\end{tabular}

DM- dry matter; NDFap - neutral detergent fiber corrected for ash and crude protein; $\mathrm{h}$ - hour; SEM Standard error of the mean; p- Probability. 


\begin{tabular}{|c|c|c|c|c|c|c|c|c|}
\hline \multirow[t]{2}{*}{ Item } & \multicolumn{5}{|c|}{ Inclusion of BRS-716 silage (\% DM) } & \multirow[t]{2}{*}{ SEM } & \multicolumn{2}{|c|}{ p-value } \\
\hline & 0 & 25 & 50 & 75 & 100 & & Linear & Quad \\
\hline $\mathrm{g} \mathrm{DM} / \mathrm{h}$ & 16.2 & 16.8 & 16.2 & 15.9 & 16.1 & 1.4 & 0.80 & 0.89 \\
\hline g NDFap/h & 4.7 & 4.7 & 5.0 & 5.3 & 5.3 & 0.5 & 0.27 & 0.97 \\
\hline
\end{tabular}

Body weight and biometric measurements

The final body weight $(P=0.89)$, weight gain $(P=0.08)$, feeding efficiency $(P=0.50)$ and the body measurements of the heifers has not been modified $(P>0.05)$ by the replacement millet silage with BRS716 silage in the diets (Table 7). The final body weight and average daily weight gain of heifers were $278.46 \mathrm{~kg}$ and $0.795 \mathrm{~kg} /$ day, respectively. 
Table 7

Body performance and biometric measurements in crossbred Holstein $x$ Zebu heifers fed diets containing different proportions of millet silage and BRS-716 silage

\begin{tabular}{|c|c|c|c|c|c|c|c|c|}
\hline \multirow[t]{2}{*}{ Item } & \multicolumn{5}{|c|}{ Inclusion of BRS-716 silage (\% DM) } & \multirow[t]{2}{*}{ SEM } & \multicolumn{2}{|c|}{ p-value } \\
\hline & 0 & 25 & 50 & 75 & 100 & & Linear & Quad \\
\hline & \multicolumn{8}{|c|}{ Performance } \\
\hline Final body weight, kg & 275.80 & 276.95 & 277.10 & 278.60 & 283.85 & 19.52 & 0.77 & 0.89 \\
\hline $\begin{array}{l}\text { Body weight gain, } \\
\mathrm{kg} / \text { day }{ }^{1}\end{array}$ & 0.735 & 0.881 & 0.768 & 0.811 & 0.781 & 0.09 & 0.11 & 0.08 \\
\hline \multirow{2}{*}{$\begin{array}{l}\text { Feed efficiency, kg } \\
\text { BWG/kg DM }\end{array}$} & 0.08 & 0.11 & 0.12 & 0.07 & 0.16 & 0.02 & 0.09 & 0.50 \\
\hline & \multicolumn{8}{|c|}{ biometric measurements, $\mathrm{cm}$} \\
\hline Thoracic perimeter & 151.90 & 151.70 & 151.50 & 151.50 & 151.90 & 4.44 & 0.98 & 0.93 \\
\hline Withers height & 121.47 & 121.85 & 121.30 & 121.05 & 121.62 & 2.43 & 0.94 & 0.94 \\
\hline Final croup height & 126.30 & 127.60 & 127.50 & 127.10 & 127.35 & 2.64 & 0.84 & 0.81 \\
\hline \multirow[t]{2}{*}{ Body length } & 129.38 & 129.95 & 129.00 & 128.80 & 129.50 & 3.55 & 0.93 & 0.94 \\
\hline & \multicolumn{8}{|c|}{ Gain, cm/day } \\
\hline Thoracic perimeter & 0.184 & 0.183 & 0.192 & 0.194 & 0.196 & 0.04 & 0.79 & 0.99 \\
\hline Withers height & 0.065 & 0.094 & 0.095 & 0.058 & 0.088 & 0.02 & 0.91 & 0.73 \\
\hline Croup height & 0.061 & 0.062 & 0.082 & 0.049 & 0.12 & 0.028 & 0.25 & 0.42 \\
\hline Body length & 0.086 & 0.169 & 0.116 & 0.085 & 0.152 & 0.03 & 0.69 & 0.94 \\
\hline
\end{tabular}

\section{Discussion}

The DM content of millet silage (24.07\%) and BRS-716 silage $(29.75 \%)$ influenced the DM content of the experimental diets, with an increase as the BRS-716 silage inclusion. This increase in DM content in the diets compensated for the decrease in DM degradability with BRS-716 silage, favoring the maintenance of DMI and nutrient intake.

The higher value of the soluble fraction "fraction a" of DM in the diet with $100 \%$ millet silage can be explained by the greater proportion of soluble carbohydrates in this silage. The higher proportion of fibrous components (NDF, ADF and iNDF) in the BRS-716 silage compared with the millet silage justify the results observed in the ruminal degradability of the silages. However, according to Van Soest (1994), 
levels of ADF above $40 \%$ can impair the DMI due to reduced digestibility. However, in experimental diets with different proportions of BRS-716 silage and millet silage, the levels of ADF did not exceed this limit, maintaining the DMI and digestibility of DM by dairy heifers in the growing phase. Additionally, the NDF intake, which has a negative correlation with the DMI due to the effect of rumen filling, was similar between diets.

Among the factors that affect animal performance, the DMI is one of the main factors when compared to environmental and sanitary factors (NRC, 2001). The similarity in the DMI and nutrients and in the digestibility of diets with different proportions of BRS-716 silage and millet silage demonstrates the forage potential of BRS-716 biomass sorghum as a roughage basis in the diet of dairy heifers. According to Gonçalves et al. (2019), the DMI has a high correlation with the production process, because in the DM are the nutrients present in the feed that can supply the needs of maintenance, gain and animal reproduction. The amount of DM ingested observed in this study was of $7.86 \mathrm{~kg} /$ day or $3.12 \%$ of BW, having a direct relationship with the increase in body weight of the animal. The greater digestibility of the ether extract with the inclusion of BRS-716 silage may reflect the higher content of this nutrient in its chemical composition.

The similarity in the TDN intake and DMI, despite the greater participation of fibrous components in the BRS-716 silage in comparison the millet silage, demonstrates that the BRS 716 biomass sorghum has compatible fiber quality to provide adequate animal performance. Corroborating with Ramos et al. (2021), who studied the effect of replacing forage sorghum silage with BRS-716 biomass sorghum silage in diets for crossbred lactating cows. The authors concluded that although the BRS-716 silage has a higher content of components fibrous (NDF; $725.6 \mathrm{vs} .664 .0 \mathrm{~g} / \mathrm{kg}$ ), its fiber is of satisfactory quality for adequate consumption. Furthermore, the authors observed that the replacement of forage sorghum silage with BRS 716 silage reduced DMI and dry matter digestibility, but did not alter the mean of milk yield (13.42 $\mathrm{kg} /$ day) and feed efficiency.

The biomass sorghum begins to have its forage potential evidenced, because, in addition to presenting high dry matter yields per hectare, it allows the obtaining of silages of good nutritional value. Almeida et al. (2019) evaluated the agronomic performance and chemical composition of six biomass sorghum hybrids for cellulosic ethanol production, observed that mutant sorghum hybrids are associated with reduced lignin content, making these genotypes more promising for enzymatic conversion processes of biomass. This fiber characteristic is common for both purposes, as there is a preference for lower lignin contents, as lignin affects in the fiber digestibility for ruminants and high percentages of lignin require higher concentrations of enzymes for the processing of biomass, making this economically unviable.

Even with the linear reduction of fecal nitrogen excretion, the nitrogen balance remained positive and similar between diets, as well as animal performance. The decrease in nitrogen excretion may result in less environmental impact and greater economic return on the production system by decreasing the use of nitrogen inputs. The nitrogen balance quantifies protein retention or loss by the animal, and is related to feed intake, when the nitrogen balance is positive it means that probably the protein requirements have 
been met (Gonçalves et al., 2014). Furthermore, despite the higher proportion of fibrous components and less energy availability with BRS-716 silage, the TDN intake and DMI were similar, justifying once again the similarity in body performance results of crossbred Holstein $x$ Zebu heifers.

The similarity for allantoin and uric acid excretions is due to the diets being isoproteic. According to Braga et al. (2012), the total excretion of purine derivatives in the urine results from protein catabolism in ruminants and are important variables for estimating the amount of synthesized microbial protein. Microbial protein synthesis was similar between diets, due to similarities in nitrogen and energy intake between experimental diets. The mean microbial efficiency verified in the diets was $130.5 \mathrm{~g} \mathrm{MCP} / \mathrm{kg}$ TDN, corroborating the NRC (2001) which proposes the value of $130 \mathrm{~g} \mathrm{MCP} / \mathrm{kg}$ TDN intake. Microbial efficiency can allow an increase in the availability of microbial protein to be absorbed in the intestine, thus meeting the requirements of growing animals (Rigueira et al., 2021).

The variations in the NDF, ADF and iNDF contents between experimental diets with different proportions of millet silage and BRS-716 silage were not sufficient to modify the ingestive behavior of heifers, which presented similar nutrients intake and digestibility values. It should be noted that the fibrous fraction is the component of the diet of main relevance under the activities of ingestive behavior, especially for diets with a high participation of roughage feeds. In the growing phase of the heifers, provide a balanced diet to ensure gain enough weight to body development and early coverage is essential. In this study, the average daily weight gain of $0.80 \mathrm{~kg} /$ day is within the desirable range, demonstrating the potential use of millet silage and BRS-716 silage for this animal category.

\section{Conclusion}

Millet silage and BRS-716 silage in the diet of crossbred Holstein $x$ Zebu heifers, used exclusively or combined in different proportions, allow dry matter intake and nutrients, digestibility, nitrogen balance, microbial synthesis, feeding behavior and performance similar body.

\section{Declarations}

\section{Acknowledgments}

The authors thank the Foundation for Research Support of the State of Minas Gerais (FAPEMIG, Brazil), Unimontes Janaúba (Experimental Farm, Brazil), the National Council for Scientific and Technological Development (CNPq, Brazil), and Instituto Nacional de Ciência e Tecnologia (INCT - Ciência Animal, Brazil). The authors would like to thank the undergraduate students for their contribution towards the accomplishment of the research.

\section{Funding information}

This study was financed in part by the Coordenação de Aperfeiçoamento de Pessoal de Nível Superior Brasil (CAPES) - Finance Code 001. 


\section{Author contribution}

FFH, VRRJ, FPM, JPSR, and DBL participated in the acquisition of data and statistical analyses of data and drafted the manuscript. VRRJ and FPM designed and conceived this study and writing of the manuscript. IDAS, MWSC, AMSA, CJBA, and DBL assisted with the preparation and interpretation of data. All authors read and approved the final manuscript.

\section{Ethics approval and consent to participate}

This study was conducted in the Experimental Feedlot of the State University of Montes Claros.

Experimental protocol (no 215/2020) and animal-use procedures were approved and followed guidelines recommended by the Animal Care Committee of the same institution. The manuscript does not contain clinical studies or patient data.

Consent for publication, Not applicable.

Consent to participate, Not applicable.

Availability of data and material, Available upon request from authors.

Code availability, Not applicable.

Competing interests/Conflict of interest The authors declare that they have no conflict of interest.

\section{References}

1. Agricultural and food research council - AFRC, 1993. Energy and protein requirements of ruminants. Wallingford: CAB International, $159 \mathrm{p}$.

2. Almeida, L.G.F.; Parrella, R.A.C.; Simeone, M. L.F.; Ribeiro, P.C.O.; Santos, A.S.; Costa, A.S.V.; Guimarães, A.G.; Schaffert, R.E. 2019. Composition and growth of sorghum biomass genotypes for ethanol production. Biomass and Bioenergy, 122:343-348.

3. AOAC International (Association of Official Analytical Chemists International), 1990. Official Methods of Analysis of the AOAC International, 15th ed. AOAC International, Arlington, VA.

4. Assis, R. L.; Freitas, R. S.; Mason, S. C. 2017. Pearl millet production practices in Brazil: a review. Experimental Agriculture, 54, 699-718.

5. Borges, L.D.A.; Rocha Júnior, V.R.; Monção, F.P.; Soares, C.; Ruas, J.R.M.; Silva, F.V.; Rigueira, J.P.S.; Costa, N.M.; Oliveira, L.L.S.; Rabelo, W.O. 2019. Nutritional and productive parameters of Holstein/Zebu cows fed diets containing cactus pear. Asian-Australasian Journal of Animal Science 18: 1-12.

6. Braga, J.M.D.S.; Valadares, R.F.; Pellizzoni, S.G.; Valadares Filho, S.D.C.; Prates, L.L.; Costa e Silva, L.F. 2012. Estimation of endogenous contribution and urinary excretion of purine derivatives from the total digestible nutrient intake in Nellore heifers. Revista Brasileira de Zootecnia, 41:1899-1906. 
7. Calegari, A.G.; Costa, A.; Lanillo, R. F.; Casão Junior, R.; Santos, D. R. 2014. Conservation agriculture in Brazil. In Conservation Agriculture: Global Prospects and Challenges, 54-88 (Eds R. A. Jat, K. L. Sahrawat and A. H. Kassam). Oxfordshire, UK: CAB International.

8. Carvalho, G. G. P., Freitas, P. M. D., Santos, E. M., Araújo, G. G. L., Oliveira, J. S., Pires, A. J. V., Maranhão, C. M. A., Rodrigues, T. C. G. C., Freitas Júnior, J. E., Rufino, L. M. A., Rodrigues, C. S., Leite, L. C., Araujo, M. L. G. M. L. 2018. Effect of pearl millet silage ammoniated with urea on lamb production and metabolic performance. Grass and Forage Science, 1:1-9.

9. Casali, A. O.; Detmann, E.; Valadares Filho, S.C.; Pereira, J. C.; Henriques, L.T.; Freitas, S.G.; Paulino, M.F. 2008. Influência do tempo de incubação e do tamanho de partículas sobre os teores de compostos indigestíveis em alimentos e fezes bovinas obtidos por procedimentos in situ. Revista Brasileira de Zootecnia, 37: 335-342.

10. Castro, F.M.R.; Bruzi, A.T.; Nunes, J.A.R.; Parrella, R.A.C.; Lombardi, J.M.R.; Albuquerque, C.J.B.; Lopes, M. 2015. Agronomic and Energetic Potential of Biomass Sorghum Genotypes. American Journal of Plant Sciences, 6:1862-1873.

11. Chen, X.B.; Gomes, M.J. 1992. Estimation of microbial protein supply to sheep and cattle basedon urinary excretion of purine derivatives - an overview of technical details (Occasional Publication). (Rowett Research Institute, International Feed Resources Unit: Bucksburnd, Aberdeen, UK)

12. Chizzotti, M.L.; Valadares Filho, S.C.; Valadares, R.F.D.; Chizzotti, F.H.M.; Tedeschi, L.O., 2008. Determination of creatinine excretion and evaluation of spot urine sampling in Holstein cattle. Livestock Science, 113: 218-225.

13. Detmann, E.; Souza, M.A.; Valadares Filho, S.C.; Queiroz, A.C.; Berchielli, T.T.; Saliba, E.O.S.; Cabral, L.S.; Pina, D.S.; Ladeira, M.M.; Azevedo, J.A.G. 2012. Methods for food analysis =Métodos para análise de alimentos. Suprema, Visconde do Rio Branco, MG, Brasil (in Portuguese).

14. Goering, H.K.; Van Soest, P.J. 1970. Forage fiber analysis (apparatus, reagents, procedures and some applications). ARS-USDA, Washington, DC. Agric. Handbook No. 379.

https://naldc.nal.usda.gov/download/CAT87209099/PDF (accessed 5 November 2020)

15. Goncalves, G. S.; Pedreira, M.S.; Pereira, M.L.A.; Santos, D.O.; Souza, D.D.; Porto Junior, A.F. 2014. Nitrogen metabolism and microbial production of dairy cows fed sugarcane and nitrogen compounds. Revista Brasileira de Saúde e Produção Animal, 15:48-61.

16. Hoffman, P.C. 1997. Optimum body size of Holstein replacement heifers. Journal of Animal Science, 75, 836-845.

17. Mertens, D.R.; Loften, J.R. 1980. the effects of starch on forage fiber digestion kinetics in vitro. Journal of Dairy Science, 63:1437-46.

18. Monção, F.P.; Santana, P.F.; Rocha Júnior, V.R.; Ruas, J.R.M.; Rigueira, J.P.S.; Borges, L.D.A.; Menezes, G.C.C.; Sousa, T.E.S.; Costa, M.D.; Oliveira, L.L.S.; Queiroz, F.E. 2020. Nutritional efficiency of feedrestricted F1 Holstein/Zebu cows in early lactation. Tropical Animal Health and Production, 52:141149. 
19. Neter, J.; Wasserman, W.; Kutner, M.H. 1985. Applied linear statistical models. Regression, analysis of variance, and experimental designs. 2. ed. USA, Richard D. Irwin, Inc., 1127 p.

20. NRC, 2001. Nutrient requirements of dairy cattle, 7th rev. ed. Natl. Acad. Press, Washington, DC.

21. Ørskov, E.R.; McDonald, I. 1979. The estimation of degradability in the rumen form incubation measurement weighted according to rate of passage. The Journal of Agricultural Science, 92:499508.

22. Queiroz, F.E.; Rocha Júnior, V.R.; Monção, F.P.; Rigueira, J.P.S.; Parrella, R.A.C.; Rufıno, L.D.A.; Santos, A.S.; Cordeiro, M.W.S. 2021. Effect of row spacing and maturity at harvest on the fermentative profile, aerobic stability, and nutritional characteristics of biomass sorghum (BRS 716) silage in the semiarid region of Brazil. Revista Brasileira de Zootecnia 50:e20200254.

23. Ramos, J.C.P.; Rocha Júnior, V.R.; Monção, F.P.; Parrela, R.A.C.; Caxito, A.M.; Cordeiro, M.W.S.; Hora, F.F.; Pires, D.A.A. 2021. Effect of replacing forage sorghum silage with biomass sorghum silage in diets for F1 Holstein $\times$ Zebu lactating cows. Tropical Animal Health and Production, 53:1-12.

24. Rigueira, J.P.S.; Jesus, N.G.; Rocha Júnior, V.R..; Monção, F.P.; Costa, N.M.; David, G.S.S.; Silva, F.V.; Carvalho, C.C.S. 2021. Effects of different banana crop wastes on nutrient intake and digestibility, microbial protein synthesis, feeding behavior, and animal performance of $3 / 4$ Holstein $\times$ Zebu heifers in a semiarid rangeland. Tropical Animal Health and Production, 53:1-13.

25. Van Soest, P.J. 1994. Nutritional ecology of the ruminant. 2.ed. Ithaca: Cornell University Press, 476p.

26. Van Soest, P.J.; Robertson, J.B.; Lewis, B.A. 1991. Methods for dietary fiber, neutral detergent fiber, and nonstarch polysaccharides in relation to animal nutrition. Journal of Dairy Science 74: 35833597.

27. Verbic, J.; Chen, X.B.; Macleod, N.A. 1990. Excretion of purine derivatives by ruminants. Effect of microbial nucleic acid infusionon purine derivative excretion by steers. The Journal of Agricultural Science, 114: 243-248.

28. Waldo, D.R.; Smith, L.W.; Cox, L.E. 1972. Model of cellulose disappearance from the rumen. Journal of Dairy Science, 55:125-129.

29. Weiss, W.P.; Conrad, H.R.; St. Pierre, N.R., 1992. A theoretically-based model for predicting total digestible nutrient values of forages and concentrates. Animal Feed Science and Technology, 39: 95-110. 